\title{
Historical Experience of China's Regional Economic Development ---A transformation from Unbalanced Strategy to Rebalancing Strategy
}

\author{
Siqi Jia ${ }^{1, a}$ \\ ${ }^{1}$ School of Economics and Statistics, GuangZhou University, 230 Wai Huan Xi Road, Guangzhou \\ Higher Education Mega Center, Guangzhou 510006, P.R. China \\ asiqi6_jia@126.com \\ * Siqi Jia
}

Keywords: Unbalanced strategy, Rebalancing strategy, Regional development, China's experience

\begin{abstract}
The experience of China's reform and opening up in the 40 years since it was put forward in 1978 can be summarized as a transformation "from unbalanced strategy to rebalancing strategy." At the beginning of the reform, China implemented the unbalanced regional development strategy that the eastern coastal region led in development. It is aimed at attracting foreign investment and undertaking industrial transfer to create a growth pole and launch the second wave of industrialization with the theme of opening to the West. However, the problems and risks caused by unbalanced development strategy began to appear at the end of the 20th century. In order to deal with these problems and risks, especially the East Asian financial crisis and the crisis of overproduction, China has initiated a large-scale infrastructure construction that mainly focuses on national investment and the strategy of rebalancing regional development, laying the foundation for the development of the central and western regions. Since the financial crisis in 2008, the speed of development of the central and western regions has been significantly superior to that of the eastern region, becoming a new engine for China's economic growth. The issue of excessively wide east-west gaps has been reversed. Furthermore, the "Belt and Road" strategy has also provided a precious historical opportunity for the rebalancing of regional development.
\end{abstract}

\section{Introduction}

From the beginning of reform and opening up to the end of the 20th century, China, under Deng Xiaoping's leadership, basically implemented an unbalanced regional development strategy. Relying on the geopolitical and policy advantages, the eastern region led in the development at that time. Deng put forward this conception in the hope of that the eastern region as an engine could drive the economic development of central and western regions after it was first developed. This conception is a typical "gradient development theory." The inevitable result of implementing such strategy is that the development gap between the eastern and western regions has been increasing in a certain period of time, even to a point of severe differentiation. Since the beginning of the new century, China has begun to carry out the strategy of rebalancing regional development. Especially since 2012, the regional development gap has been reduced to a certain extent while maintaining economic growth in a medium-high speed. In fact, both the unbalanced strategy and the rebalancing strategy in regional development have stood an important position in the rapid development of China's economy at the corresponding stage. The historical process of the transformation of China's regional development strategy and different mechanisms for promoting China's economic development at different historical stages are analyzed in this article. 


\section{Export-oriented Economy Mode and the Leading Development Strategy in Eastern Region}

\subsection{The Transfer of Global Manufacture and the Formation of "World Factory" in Eastern Coastal Areas}

In the 1960s, Singapore, South Korea, Hong Kong, China and Taiwan, China, which are called as "The Four Asian Tigers", adopted an export-oriented strategy to undertake the transfer of laborintensive industries from the United States and Japan and boosted their economic growth. In the 1970s and 1980s, "The Four Asian Tigers" had basically realized industrialization and modernization, gradually lost the price advantage of land and labor, and continued to attach importance to the development of capital and technology-intensive industries. Under this background, the eastern coastal regions of China, represented by Guangdong province, have successfully undertook the transfer of labor-intensive industries from "The Four Asian Tigers" and other developed countries by virtue of their geographic advantage and good human relations. The export-oriented industry with "the three-processing and one compensation" as its main content has gained a rapid development.

This transformation has an important relationship with China's high-level strategic decisions and special considerations at that time. At the end of 1978, the Communist Party of China held the Third Plenary Session of the Eleventh Central Committee. At this session, the conception of using economic development to replace political struggle to be the country's strategic focus was put forward. China began to fully open to the West and introduced its capital and technology into our country. Based on the experience and lessons of economic construction in the Mao era, the Chinese leaders at that time, combined with the different regional and resource advantages of China's various regions and changes in the international situation, proposed an unbalanced development strategy that "the government encourages some people and regions to be prosperous prior to others so that those people and regions can then bring along the latter poorer. Finally, the prosperity for all can be realized." They put forward this strategy in the hope of promoting the gradient-based development of the regional economy. The regions identified as priority areas for development are the southeast coast regions in China. During the implementation of the "6th Five-Year Plan" (1980-1985), the Chinese government clearly stated that it is necessary to actively use the existing basis of coastal areas and "fully develop their expertise to drive further economic development in the Mainland" when it came to opening up. The establishment of special economic zones and open coastal cities are beneficial to gradually build a hierarchical open system and to loosen restrictions on foreign economic exchanges.

In order to firstly promote the development of the eastern coastal areas, the central government has given a series of policy support to these areas, especially given some institutional space to break through the current system. In addition, the region's own regional advantages at the time, such as convenient external transportation, well-informed information, low land costs, proximity to the capital source and industrial transfer places-Hong Kong, Taiwan, and Southeast Asia, as well as rich Chinese and overseas Chinese resources, have continuously improve the economic level of the eastern coastal economic belt.

According to Figure 2-1, taking the China's Pearl River Delta, Yangtze River Delta, and Shandong Peninsula, which are represented by Guangdong, Zhejiang, and Shandong Provinces, as examples, the share of import-export value accounting for the China's total in these areas are also increasing in varying degrees with the deep spread of reform and opening up, presenting a good development trend in the external economy. Among them, the most striking growth trend in Guangzhou province is can be seen a microcosm of the export-oriented economy in the eastern coastal areas. 


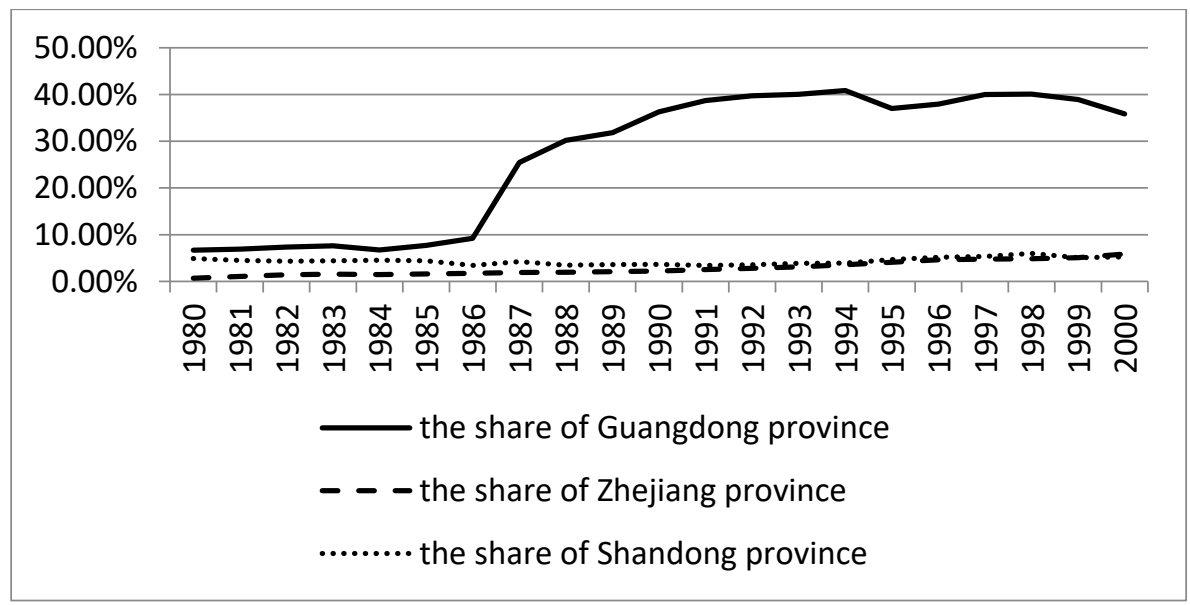

Fig.2-1 Share of Total Country Import-Export of Guangdong, zhejiang and Shandong provinces

Table 2-2 the Contribution Rate of Import-Export Trade to GDP Growth in Eastern Coastal Areas

\begin{tabular}{|c|c|c|c|}
\hline Year & $\begin{array}{c}\text { Net Exports Increment } \\
\text { (billion) }\end{array}$ & $\begin{array}{c}\text { GDP Increment } \\
\text { (billion) }\end{array}$ & $\begin{array}{c}\text { Contribution Rate of Foreign Trade } \\
\text { to GDP Growth }\end{array}$ \\
\hline 1980 & 46.16 & 227.09 & $20 \%$ \\
\hline 1981 & 10.17 & 199.97 & $5 \%$ \\
\hline 1982 & -5.13 & 260.37 & $-2 \%$ \\
\hline 1983 & -2.88 & 280.76 & $-1 \%$ \\
\hline 1984 & -16.67 & 580.79 & $-3 \%$ \\
\hline 1985 & -34.26 & 755.01 & $-5 \%$ \\
\hline 1986 & -75.15 & 514.64 & $-15 \%$ \\
\hline 1987 & 143.38 & 956.33 & $15 \%$ \\
\hline 1988 & -79.42 & 1591.26 & $-5 \%$ \\
\hline 1989 & 34.62 & 1000.32 & $3 \%$ \\
\hline 1990 & 289.95 & 864.75 & $1 \%$ \\
\hline 1991 & 17.83 & 1575.78 & $-5 \%$ \\
\hline 1992 & -131.82 & 2758.71 & $-5 \%$ \\
\hline 1993 & -224.62 & 4895.89 & $7 \%$ \\
\hline 1994 & 458.76 & 6261.45 & $6 \%$ \\
\hline 1995 & 416.95 & 6572.08 & $-1 \%$ \\
\hline 1996 & -75.13 & 5343.92 & $14 \%$ \\
\hline 1997 & 682.66 & 4724.22 & $-10 \%$ \\
\hline 1998 & -351.41 & 3520.42 & $-2 \%$ \\
\hline 1999 & -65.33 & 3432.46 & $6 \%$ \\
\hline 2000 & 368.14 & 6098.22 & 5 \\
\hline
\end{tabular}

The Table 2-2 shows that the average contribution rate of foreign trade to economic growth in the eastern coastal areas of China during 1980-2000 was 3\%, which indicated that the development of export-oriented economy in the eastern coastal areas had promoted the growth of the national economy. The implementation of the unbalanced strategy has markedly improved the overall level and speed of China's economic development, gave full play to the advantages of regional resources and geographic location, and effectively improved China's comprehensive national strength.

\subsection{Widening Regional Disparity--The Negative Effect of Unbalanced Development Strategy}

Thanks to the unique geographical advantages and the support of special government policies, the economy in eastern region has developed with a rapid speed. As a result, resources, capital, and labor in the central and western regions have largely flown to the east coastal areas, resulting in the development gap between the eastern and western regions has gradually widened. 


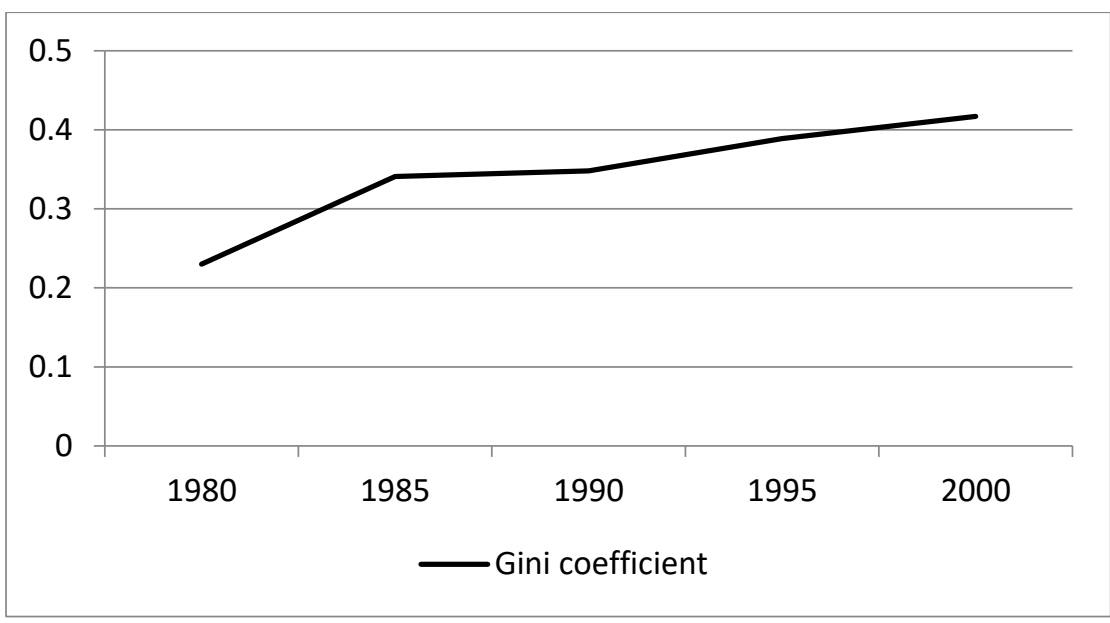

Fig.2-2 Change Trend in China's Gini Coefficient from 1980 to 2000

The change trend of the Gini coefficient in China from 1980 to 2000 also reflected the gradual widening of the economic development between eastern and central and western regions.

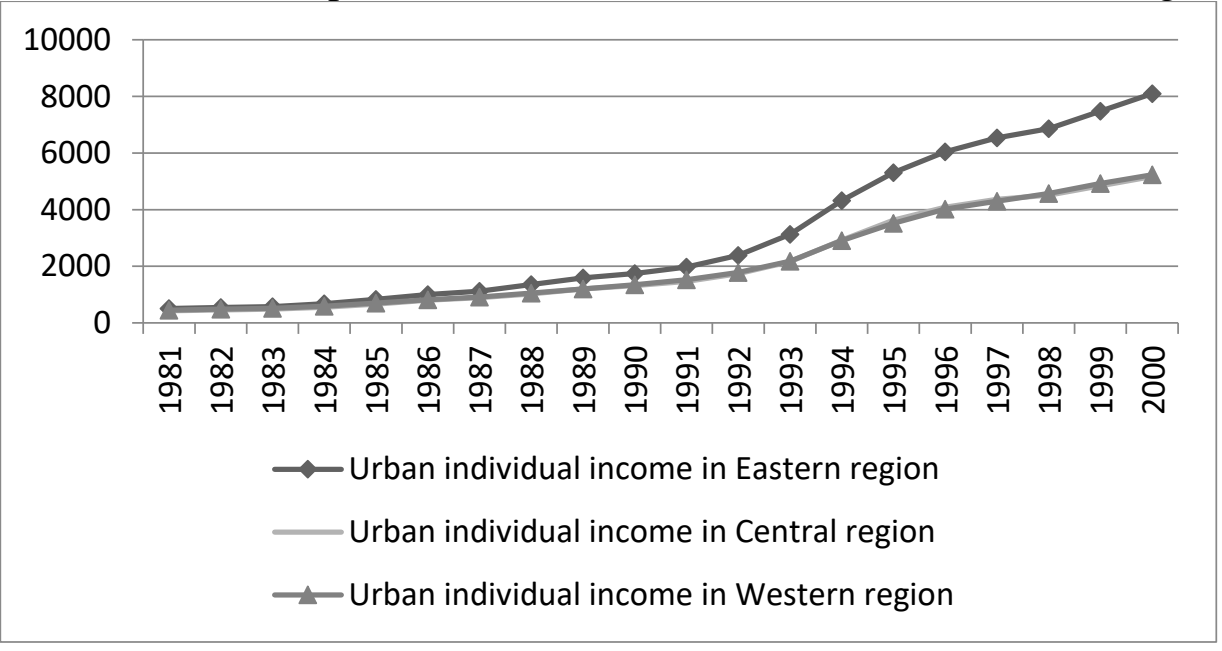

Fig.2-3 Per Capita Income of Urban Residents between Eastern and Central and western regions in China from 1981 to 2000

From the data, the per capita income of urban residents in the central and western regions is very close, but there is a widening gap from the eastern region.

The level of urbanization is an important reflection of the status of regional economic and social development. In the process of urbanization, there is also a large gap between the eastern and central and western regions. According to statistics, in 2000, the urbanization rate in eastern China was 45.5\%, $39.4 \%$ in the middle, and $29.5 \%$ in the west. The level of urbanization in the central and western regions significantly lags behind the eastern region.

The level of industrialization is also an important indicator for evaluating regional economic development. Differences in the level of industrialization cause differences in the regional economy. Furthermore, the lag in industrialization also affects the development of the regional economy. It is not difficult to see from the following figure 2-4 that the industrialization levels in the central and western regions also lag behind those in the eastern region for a long time. 


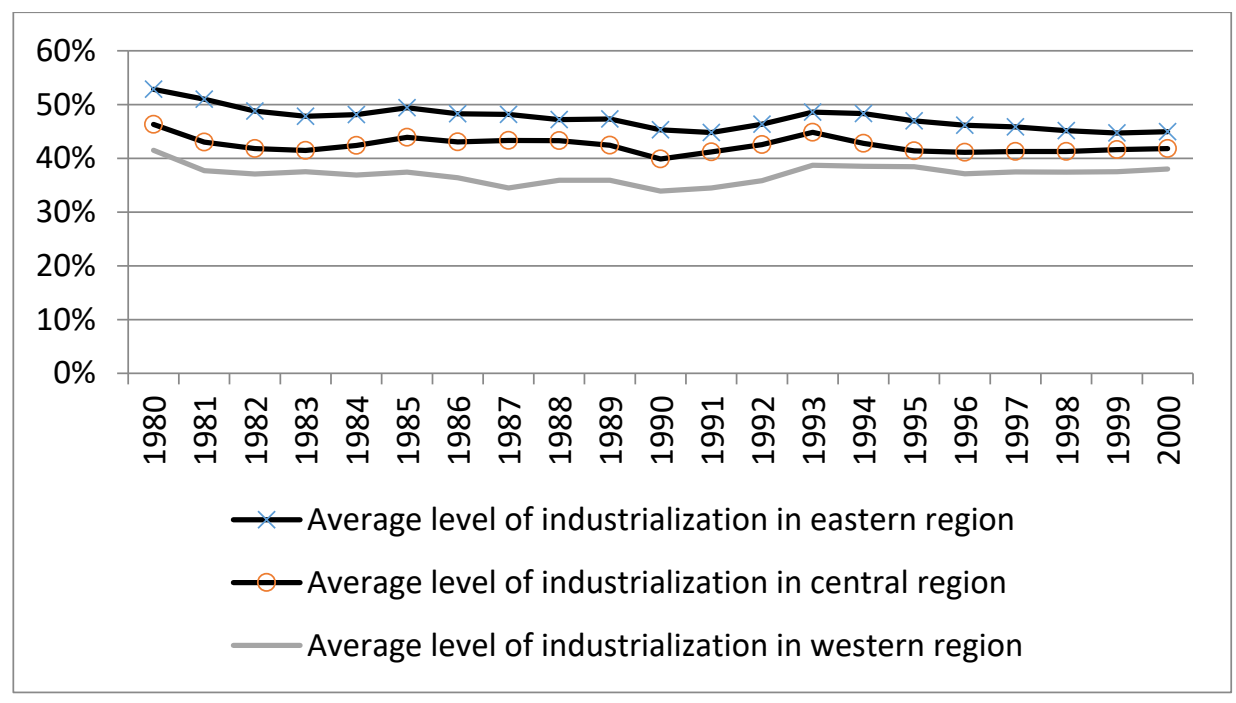

Fig.2-4 Comparison of Average Level of Industrialization between Eastern and Central and Western Regions

The overlarge differences in regional economy have made the resources, capital and labor forces in central and western regions continue to shift to the eastern region. Therefore, the development of the central and western regions has been slow. This consequence has been particularly prominent in the vast rural areas of the central and western regions. Large amounts of land have been occupied due to urbanization, large amounts of capital have been taken up by the eastern region, and hundreds of millions of migrant workers have left their homes to work in the coastal areas. The rural areas in the central and western regions have fallen into decline.

\subsection{Import-oriented Economic Crisis--The Overall Risk of Export-oriented Mode}

With the accelerating process of economic globalization, various countries and regions in the world have penetrated, integrated, and interdepended deeply with each other in economy. This has provided opportunities for the rise of developing countries, but it has also brought negative effects. Under the export-oriented economic development mode, the dependence of the Chinese economy on the international market is also increasing, and it is more directly affected by the fluctuation of the international economy. Since the scope and scale of world trade are constantly expanding, the foreign trade situation of a country will also be greatly affected by it when the economic crisis occurs. China is no exception. In the outbreak of the East Asian financial crisis in 1997, China's exports fell sharply, with the driving force for exports to economic growth fell from $4.2 \%$ in the previous year to $1.3 \%$ in 1998. In 1998, the total value of exports grew by only $0.5 \%$, while the value of general trade exports fell by 4.8\% year-on-year. (Wen Tiejun 2013) The Chinese economy in the 1990s was still in its infancy. In 1998, the per capita national income was only CNY2322.09. Also, China's cities were in a period of deflation with the low overall consumption of residents. In the troika that drives economic growth, exports have been greatly affected by the import-oriented Asian financial crisis. People's consumption ability has been limited by their low income. Ultimately, the hope of driving economic development is only put to investment. As China has long been promoting the development of military heavy industry in the form of state capitalism since 1949, the private economy and private capital had continued to be in relatively weak status. The consequence was that the final investment subject can only be the government. Because of the reform of the tax-sharing system in 1994, the financial resources of the central government have greatly increased, but local governments have been in short supply. Therefore, the central government can only rely on the large-scale capital construction investment to stimulate economic development and overcome the crisis.

Therefore, when the economic crisis hits the east region, the government can also increase the national investment in the central and western regions to maintain rapid economic growth and relatively improve the conditions for infrastructure in those regions. This is the beginning of rebalancing of China's regional development. 


\section{China's "Roosevelt New Deal" - Rebalancing National Public Finance Expenditure and Government Revenue}

During the Great Depression of 1929-1933, President Roosevelt of the United States adopted a series of new policies to expand direct or indirect government intervention in the economy through industry recovery, social relief, reform of the financial system, work relief, and construction of public works, which effectively alleviated the economic crisis and social conflicts brought about by the Great Depression. In 1998, China adopted a similar policy to deal with the Asian financial crisis. At the time, Premier Zhu Rongji decided to implement a proactive fiscal policy, through the central government's large-scale investment in infrastructure construction in the central and western regions to defuse the overcapacity caused by the financial crisis. This policy laid a solid foundation for China to rebalancing regional economy and became the "Roosevelt New Deal" of a Chinese version.

\subsection{Sources of Funds for Large-scale National Fiscal Investment}

As the 1994 Budget Law of the People's Republic of China prohibited the Ministry of Finance from borrowing from the Central Bank, the scale of Chinese national debt increased rapidly. In addition to the Asian financial crisis which broke out in 1998, both domestic demand and foreign demand were suppressed at the same time, resulting in lacking momentum in economic growth. To address this problem, the Chinese government formulated a fiscal financing strategy for "providing long-term special national debt at a moderate rate and raising medium and long-term national debt in China at the same time." Through the release of medium and long-term national debt, a part of short-term funds can be converted into medium and long-term funds for the construction of large-scale projects to promote economic development.

In addition, the "Decision on Implementing the Tax-Sharing Fiscal Management System" promulgated in 1993 pointed out that from January 1, 1994, the current system where local authorities take full responsibility for their finances were reformed, and the tax-sharing system of financial management was implemented in all provinces, autonomous regions, municipalities and municipalities with independent planning status. This made the central government get a large part of its fiscal revenue and local governments get a small part of it. The tax-sharing system has led to a large-scale increase in central government revenues and disposable financial resources, and enhanced regulatory capacity over economy.

Finally, on January 1, 1998, the People's Bank of China cancelled the credit limit control system. Under the new system, state-owned commercial banks have been granted greater independence, but they still need to follow the instructions of the People's Bank of China. In the same year, the People's Bank of China carried out major reforms in its management system. The main measures were to cancel the provincial branches of the People's Bank of China and set up branches of the People's Bank across provinces (autonomous regions and municipalities) so as to enhance the independence of the People's Bank of China and enable it to conduct financial supervision and implement monetary policies without any influences. To view China's financial system reform from a long-term, China's financial system reform was a top-down reform with government intervening. As Lin Yifu said, the compulsory institution evolution was carried out by the government forcibly and mainly driven by the government's interests and preferences.

The Chinese government raised large amounts of funds from the three aspects demonstrated above, and the funds laid a solid foundation for large-scale financial investment.

\subsection{Large-scale Infrastructure Investment to Solve Overcapacity Crisis}

Because of the Asian Financial Crisis, China experienced the first large-scale overcapacity as exports declined. According to the classical Keynes theory, when a country is in imbalanced economic state, it should use financial deficits to directly create investment and consumption to start market, create jobs and promote economic growth. In 1999, China issued CNY371.5 billion national debt (about twice the 1995 national debt). In 2000, it issued CNY465.7 billion national debt. The issuance of large-scale national debt and the increase in financial investment have enabled the country to carry 
out large-scale infrastructure construction in the central and western regions and improve infrastructure and public services in these regions. In terms of transportation construction, in 1999, the length of railway lines in the western region increased by $23.19 \%$, highway mileage increased by $30.13 \%$, and inland waterways increased by $21.94 \%$. In public services, the rural electricity rate in the western provinces except Tibet and Qinghai reached or exceeded the country's rural electricity rate of $98.31 \%$ (Xie Xiaoxia 2001). Proactive fiscal policies also effectively stimulated economic growth. The GDP growth rate rose from $7.83 \%$ in 1998 to $9.08 \%$ in 2002 .

Wen Tiejun (2013) talked about overcapacity and concluded that the main measures taken by China in the past were to strengthen macroeconomic regulation and control, intervene in the economy, and shift the huge overcapacity to inland construction to invest in changing three major differences strategically. Investments have been made in rebalancing differences of regions, urban-rural areas and gap of wealth. Afterwards, during Hu and Wen's administration, they decided to continue to start a series of strategies including revitalizing the old industrial base in northeast China, the rise of central China, and the construction of new countryside to expand government financial investment and resolve excess production capacity.

\subsection{Another Result to Solve Crisis: Regional Development Rebalancing}

Since the end of the 1990s, coping with the economic crisis and resolving excess capacity, the Chinese government has also objectively improved infrastructure level, public services, and people's living standards in the central and western regions through its large-scale financial investment, especially through central finance. To a certain extent, it has played a role in reversing the unbalanced regional development and the excessive development gap between urban and rural areas. It has also laid a foundation for China to regain economic growth and realize common prosperity in the central and western regions after the realization of industrialization currently.

Table 3-1 Regional Development Rebalancing Strategy in different stages

\begin{tabular}{|c|c|c|c|}
\hline Strategy Name & $\begin{array}{l}\text { Propos } \\
\text { ed } \\
\text { Time }\end{array}$ & Coverage & Investment Scale \\
\hline $\begin{array}{l}\text { The great western } \\
\text { development } \\
\text { strategy }\end{array}$ & 1999 & $\begin{array}{l}12 \text { provinces, autonomous regions } \\
\text { and municipalities: Chongqing, } \\
\text { Sichuan, Guizhou, Yunnan, Tibet, } \\
\text { Shaanxi, Gansu, Qinghai, Ningxia } \\
\text { Hui Autonomous Region, Xinjiang } \\
\text { Uygur Autonomous Region, Inner } \\
\text { Mongolia Autonomous Region, } \\
\text { Guangxi Zhuang Autonomous } \\
\text { Region. }\end{array}$ & $\begin{array}{l}\text { From } 2000 \text { to } 2012 \text {, the cumulative } \\
\text { investment was } 3.68 \text { trillion yuan. }\end{array}$ \\
\hline $\begin{array}{l}\text { Revitalizing the } \\
\text { Northeast Old } \\
\text { Industrial Base }\end{array}$ & 2003 & Northeast Region & $\begin{array}{l}\text { In } 2003 \text {, China invested } 11 \text { billion yuan } \\
\text { in a hundred projects to revitalize } \\
\text { northeast region. }\end{array}$ \\
\hline $\begin{array}{l}\text { The Rise of } \\
\text { Central China }\end{array}$ & 2004 & $\begin{array}{l}6 \text { provinces: Shanxi, Henan, Hubei, } \\
\text { Hunan, Anhui, Jiangxi. }\end{array}$ & $\begin{array}{l}\text { From 2006-2010, the central finance } \\
\text { general transfer payment to the central } \\
\text { region amounted to } 1.35 \text { trillion yuan. }\end{array}$ \\
\hline $\begin{array}{l}\text { The construction } \\
\text { of new socialist } \\
\text { countryside }\end{array}$ & 2005 & National Rural Area & $\begin{array}{l}\text { In } 2006 \text {, rural-areas supporting funds } \\
\text { reached } 339.745 \text { billion yuan. }\end{array}$ \\
\hline $\begin{array}{l}\text { Targeted Poverty } \\
\text { Alleviation } \\
\text { Strategy }\end{array}$ & 2013 & National poor residents & $\begin{array}{l}\text { In } 2016 \text {, the National Financial Special } \\
\text { Poverty Alleviation Fund exceeded } 100 \\
\text { billion yuan. }\end{array}$ \\
\hline
\end{tabular}

\subsubsection{The great western development strategy}

In June 1999, Jiang Zemin proposed that the conditions for China to accelerate the pace of development in the central and western regions are already in place and the timing is ripe. In November that year, the deployment of the Central Economic Work Conference pointed out that we 
must seize the opportunity to start the strategy for the development of the western region. During the implementation of the great western development, China carried out infrastructure construction such as water conservancy, transportation, and power networks for the western region, laying a good foundation for the development of the western region. At the same time, after a period of rapid development, the eastern region was facing the pressure of structural adjustment and industrial upgrading. There were many surplus products that require a broader market. In addition, since the founding of the People's Republic of China, the country has planned and built a large number of energy and industrial projects in the western region, laying the foundation for the industrialization of the western region. The great development of the western region has coordinated the regional relations between the eastern and western regions to some extent and laid the foundation for the rapid economic growth in the western region.

\subsubsection{Revitalizing the Northeast Old Industrial Base}

In 2003, the central government of China officially proposed the strategy for revitalizing the northeast old industrial base, which was a plan to revitalize the industry and economy in the northeast by providing funds and other aids and implementing preferential policies. Although the growth rate of the three provinces of northeast region still ranked at the bottom in the past ten years, secondary industries, transportation construction such as railways and highways, and imports and exports trades have developed.

\subsubsection{The rise of Central China}

In 2004, Premier Wen Jiabao first proposed to implement the strategy of the central China economic zone - the rise of the six provinces of Shanxi, Shanxi, Henan, Hubei, Hunan, Anhui and Jiangxi. Afterwards, the rise of Central China also increased the Central Inner Mongolia and Guangdong Province to the northeast of the western part of Guangdong Province based on the former six central provinces. The Plan for Promoting the Rise of the Central Region emphasized the "three bases and one hub" in the central region. The "three bases" are evident advantageous resources. The middle part has fertile land resources and is one of the major grain producing areas in China. In terms of energy raw materials, Shanxi, Henan West, Hubei, and Anhui are rich in coal resources, and the region also has abundant water resources; In terms of equipment manufacturing, there are many excellent heavy industrial cities such as Wuhan, Changsha, Zhuzhou, Zhengzhou, Taiyuan, Hefei, and Nanchang. The hub referred to the "two horizontal and two vertical" economic belts of the Yangtze River, Bohai Sea, Beijing-Guangzhou and Beijing-Jiujiang and it was directly related to the positioning of the "transportation hub" in the region. The rise of central China planned to increase the level of economic development and accelerate the adjustment and optimization of the industrial structure in the central region.

\subsubsection{The construction of new socialist countryside}

To narrow the development gap between urban and rural areas, the CPC Central Committee in 2005 proposed a plan to develop agriculture and build a new countryside. For a long period of time, the dual economic structure had forced the rural areas to export large amounts of cheap resources, capital, and labor to support the development of the city. Agriculture and the countryside itself had fallen into recession. The living standards of farmers in most parts of China were low. The new rural construction has greatly improved the basic production and living conditions in rural areas. When the financial crisis broke out in 2008, tens of millions of unemployed migrant workers along the Chinese coast returned home without social turmoil while they stayed in China; China's export processing industry, which has been influenced greatly, has been able to export domestically through the "three links" such as water, roads, and electricity in the middle and western rural areas. The overproduction has been resolved.

\subsubsection{Targeted Poverty Alleviation Strategy}

In 2013, the Chinese government led by Xi Jinping began to implement the "Targeted Poverty Alleviation" Strategy. This is a continuation of the previous strategy of reconstructing the new rural construction and regional development. The Chinese economy entered a new normal around 2012, with overcapacity in all aspects and a sharp drop in exports. The Targeted Poverty Alleviation Strategy 
can be seen as the "latest version" of the Roosevelt New Deal.

\subsection{The Chinese Version of the "Roosevelt New Deal"}

After China implemented "New Deal" of a Chinese version around 2000, the proportion of three driving forces for China's economy began to change and the economy started to grow rapidly.

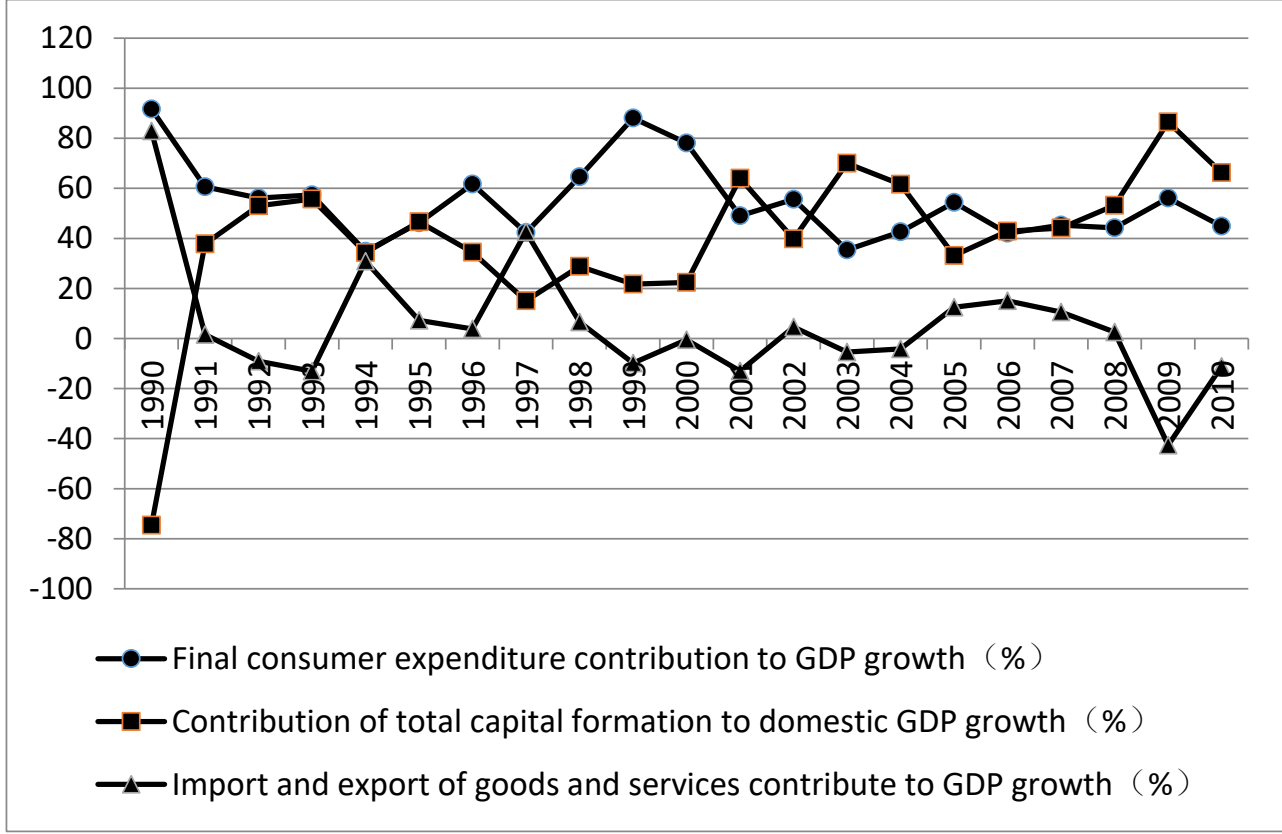

Table 3-1 Contribution rate of three major demands for domestic GDP growth

On one hand, according to table 3-1, investment has contributed more and more in economy and reached its peak at 2009. Although the central government did not have an immediate short-term effect on the infrastructure construction in the central and western regions through fiscal investment, it has achieved significant results in stabilizing the unemployment rate, promoting economic growth, and overcoming the problem of regional surplus rebalancing. From 2000 to 2007, the registered unemployment rate in urban areas remained $4.1 \%$, and the growth rate of GDP increased from $8.4 \%$ to $14.2 \%$ moderately.

On the other hand, the central and western regions and more and more rural areas have successfully accessed to water and electricity, and infrastructure such as expressways and high-speed railways have been gradually improved, providing basic conditions for later development in these regions. China's regional economic situation began to change, and regional development has become more balanced.

\section{Rebalancing of Regional Development -- Reshaping China's economic landscape}

With the increasing costs of labor and land, the eastern China has lost its original advantage of developing labor-intensive industries. The aforementioned several national strategies of balancing regional and urban-rural gap are aimed to address overcapacity. And it has brought fundamental improvements in infrastructure and public services in central and western regions, and the rapid industrialization and urbanization in the central and western regions. The regions have become a new driver of economic growth in China. And the new engine for growth, together with the "the Belt and Road" initiative that is opened to the west, has brought the rebalancing of China's regional development centered on the rise of the central and western regions. More importantly, it is also a key strategy for China to respond to international economic and geopolitical challenges. 


\subsection{Rapid Development of Industrialization and Urbanization in the Central and Western Regions}

In recent years, the central and western regions have actively taken advantage of their cheap land and labor resources to accept industrial transfer from the eastern region, turning resources superiority into the favorable economic conditions and upgrading industrialization. Among them, Foxconn Group, the global electronics Original Equipment Manufacturer giant, moved from Shenzhen to mainland China was the best example. The land and labor costs in Shenzhen are increasing, and the industrial structure is in urgent need of transformation. Thus Foxconn's relocation to mainland is a strategic choice of which advantages far outweigh its disadvantages. On the one hand, it can stimulate the construction and development of industrial parks in mainland China while it also effectively utilizes cheap production factors in mainland areas to save production costs. In addition, due to the weak external trade in the eastern region, more and more enterprises in the eastern region have begun to use the huge consumer market in the central and western regions to gradually shift overcapacity to rural areas and turn to sell consumer goods on domestic market. The industrialization of the central and western regions has thus been developed and achieved significant results. In 2014, the growth rates of the industrial added value of the five provinces in the central region except Shanxi Province were all higher than $11 \%$ year-on-year; the growth rates of most provinces in the western region were all higher than the national average.

In addition, in recent years, with the rapid development of urban agglomerations in the central and western regions, the overall level of its urbanization has been unceasingly enhanced. These urban agglomerations include Central Plains Urban Agglomeration, Yangtze River Delta Urban Agglomerations, Chengdu-Chongqing City Group, Guanzhong plain city group and so on. The rapid rise of various urban agglomerations has accelerated the development of new-type urbanization in China. From 2012 to 2016, the urban population in the central and western regions increased from $47 \%$ and $44.73 \%$ to $52.77 \%$ and $50.19 \%$, respectively. At present, the level of urbanization in the central and western regions is still at a rapid growth stage and gradually grows matured.

\subsection{The economic growth momentum in the central and western regions continuously strengthens}

Since 2012, the speed of growth in the central and western regions has become faster and faster, resident income and consumption levels are continuously increasing. The growth rate of some regions such as Chongqing in the central and western regions has caught up with or even surpassed the rate of eastern coastal areas. The growth rate in the northeast region is lower than that in the eastern region, which represents the regional development of eastern and central areas have become more balanced. However, it is quite difficult for the eastern region to recover its economic growth to the level of the initial stage of reform and opening up as a result of the deepening of industrial transformation, and the difference of speed of economic growth between the eastern and western regions may last.

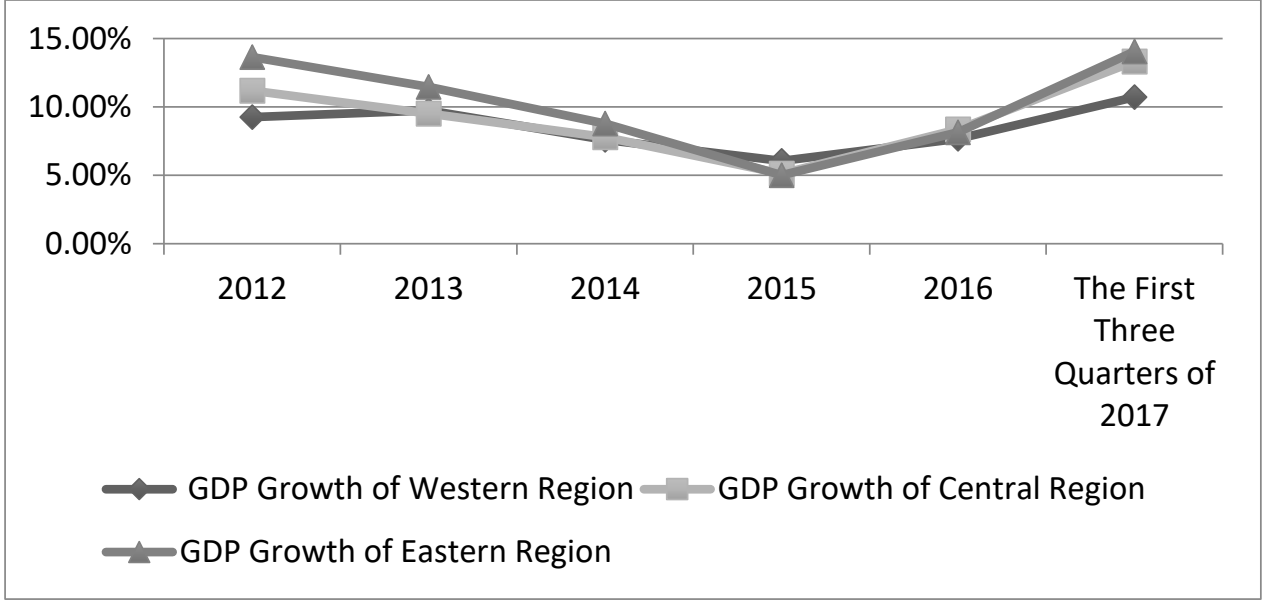

Figure 4-1 Comparison of GDP Growth Rates in the Eastern, Central, and Western Regions 


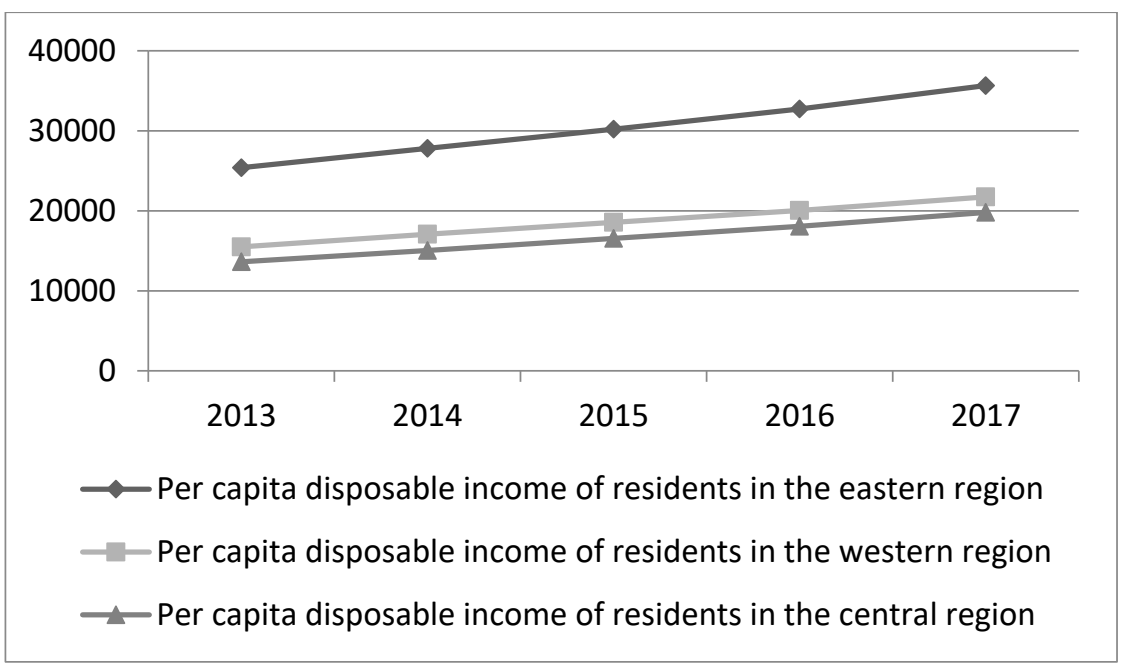

Figure 4-2 Per Capita Disposable Income of Residents in Eastern, Central and Western Regions

\section{3 "the Belt and Road" Initiative and the Prospect of Reshaping China's Economic Landscape}

Today, the central and western regions have become new growth engines for the Chinese economy. Under the "the Belt and Road" initiative, the central and western regions are also bound to become the country's emphasis of strategic investment and industrial transfer. The "the Belt and Road" strategy was first proposed by Chairman Xi Jinping in 2013. It mainly refers to the Silk Road Economic Belt and the 21st Century Maritime Silk Road. The Silk Road on land has mainly expanded westward, closely connecting China with Central Asia and Europe. China's central and western regions and border areas have become the areas closest to the market from the original distance from the market, and have become the gateway and link between China and many neighboring countries. This is of great significance to China's transfer of excess production capacity and the promotion of trade development. Currently, many major projects have been implemented in "the Belt and Road" initiative, mainly including some infrastructure construction, such as the start of the "Maiba Highway" in central Afghanistan construction project assisted by China, the financial and technical assistance to Pakistan's Gwadar port, Kazakhstan's Central Asian natural gas pipelines project, and the operation of China Railway Express, are mostly win-win projects. Take the example of the ChongqingSinkiang-Europe International Railway in the China Railway Express. As of 2017, the ChongqingSinkiang-Europe International Railway has already opened nearly 700 expresses. Among them, the transported goods of departure are mainly laptops, industrial machinery parts and household appliances and accessories; the transported goods of return are mainly auto parts and industrial machinery parts. The opening of the Chongqing-Sinkiang-Europe International Railway has promoted the export of a large quantity of electronic products that is from East China and South China to Europe. A wave of world-renowned transportation enterprises, such as NTT (Nippon Telegraph and Telephone Public Corporation), Kuehne \& Nagel Group, and Deutsche Bahn, have expanded their business to Chongqing. Chongqing-Sinkiang-Europe International Railway has become an important channel for China-EU trade and an important carrier for implementing "the Belt and Road" strategy and the Yangtze River Economic Belt. On the other hand, through the establishment of the Maritime Silk Road and the Asian Infrastructure Investment Bank, the eastern region can also take advantage of its adjacent geography, high open-up degree of economic zone, strong economic strength, and radiating and exemplary role to connect with the markets of major economic sectors such as ASEAN, South Asia, West Asia, North Africa and Europe, and carry out economic cooperation with them. This has profound implications for forcing deep-level reforms through the expansion of opening up in the eastern region. And this is also of great significance to form an innovative and open economic system and the new advantages of international cooperation and competition.

Through the "the Belt and Road", China has obtained new opportunities for development in areas 
such as transportation infrastructure, trade and investment, energy cooperation, regional integration, and RMB internationalization. In general, "the Belt and Road" initiative is an important opportunity for reshaping China's economic landscape. Let us wait and see its effects.

\section{References}

[1] Wei Houkai. China's National Regional Policy Adjustments and Prospects [J]. Development Research. 2009 (05):22-27

[2] Ma Bianjing. An Empirical Study on the Influencing Factors of Economic Disparity in China [D] Huazhong University of Science and Technology.2011.1-131

[3] Wang Lu. An Empirical Analysis of China's National Debt Policy Drives Domestic Demand from 1998 to 2007[D].Southwestern University of Finance and Economics.2009:1-66

[4] Jiang Guiqin. On China's Financial System Reform [D].Anhui University.2004:1-58

[5] Wen Tiejun, Yang Haixia, Liu Jie, Jiang Maosen. A Dialogue to Wen Tiejun Three Issues in Agriculture and China's Road [J]. China Investment, 2013(11):25-35+24+11.

[6] Wang Xiaoling, Fang Xingcun. Evaluation of Economic Revitalization Efficiency of Northeast Old Industrial Base and Analysis of Influencing Factors [J]. 2017(01):69-74

[7] Xie Xiaoxia. Analysis of Infrastructure in Western Region [J].China Industrial Economics, 2001, (10):60-64.

[8] Zhang Qin. An Analysis of Industrial Transfer and China's Industrial Acceptance: Based on the Empirical Analysis of "Four Little Dragons" in Asia [J].Theory and Reform.2010, (01):78-80 